\title{
Advances in Large Grain/Single Crystal SC Resonators at DESY
}

\author{
Presented by W.Singer
}




\section{Participants}

X.Singer, H.Wen, A.Ermakov (DESY, MPL)

D. Proch, A.Brinkmann, J.Iversen, G.Kreps, D.Reschke

(DESY, MHF-SL)

A.Matheisen, A.Schmidt (DESY, MKS3)

M.Spiwek (DESY HASYLAB)

P.Kneisel (JLab)

K.Kowalski, A.Bernasik (SSL, Krakow)

A.Dangwal, G.Mueller (UNI Wuppertal)

K.-R. Baldner, J. Van Santen (RWTH Aachen) 


\section{Outlook}

- LG: Fabrication and some results

- SC: Fabrication and some results

- Material investigation 


\section{Fabrication of fine grain $\mathrm{Nb}$ sheets}
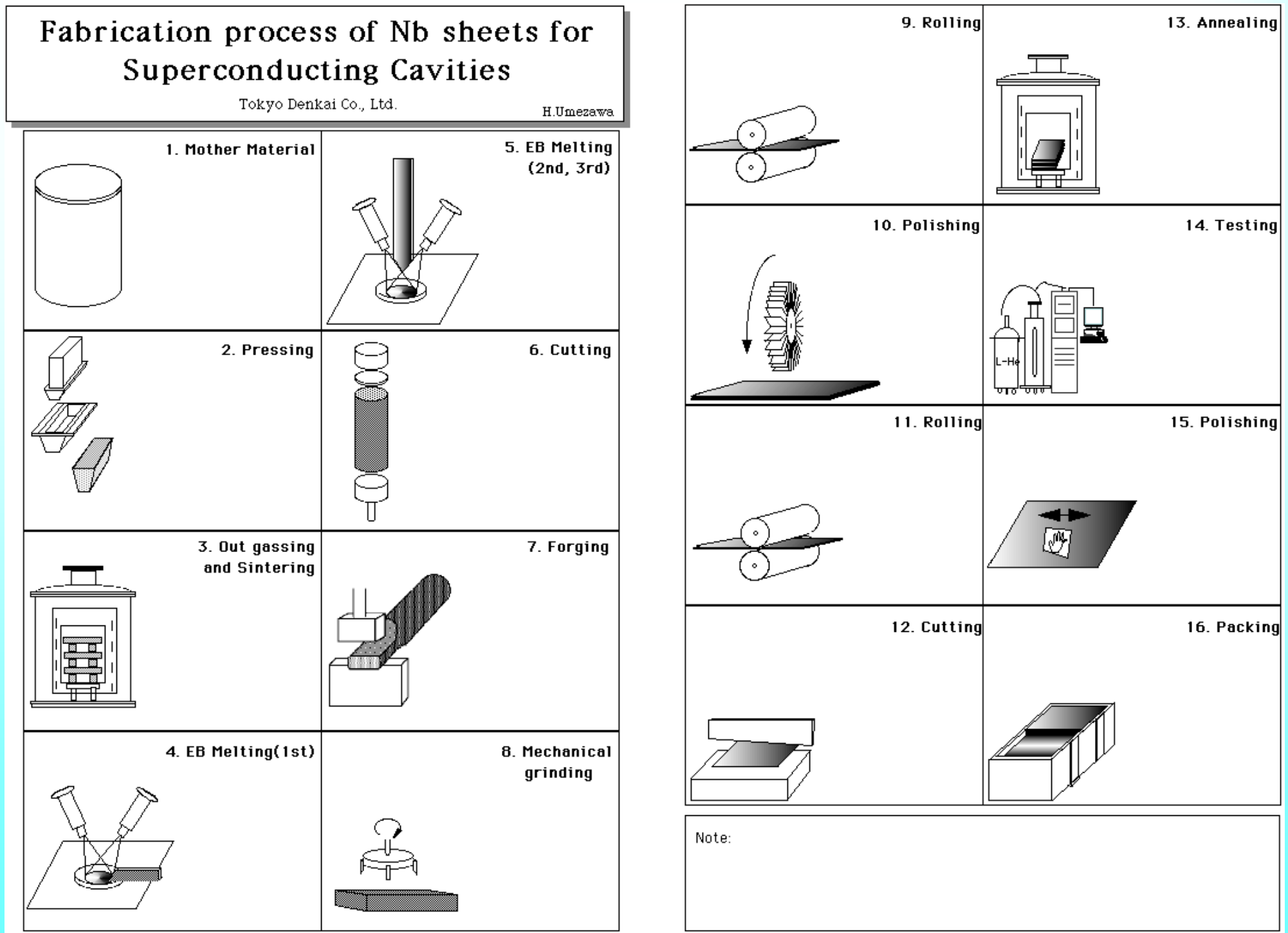

W.Singer, CARE06 Annual Meeting, Frascati, 15 -17 November 2006 


\section{Large Grain/Single crystal... Proposed by G.Rao (JLab), P.Kneisel (JLab), T. Carneiro (CBMM)}
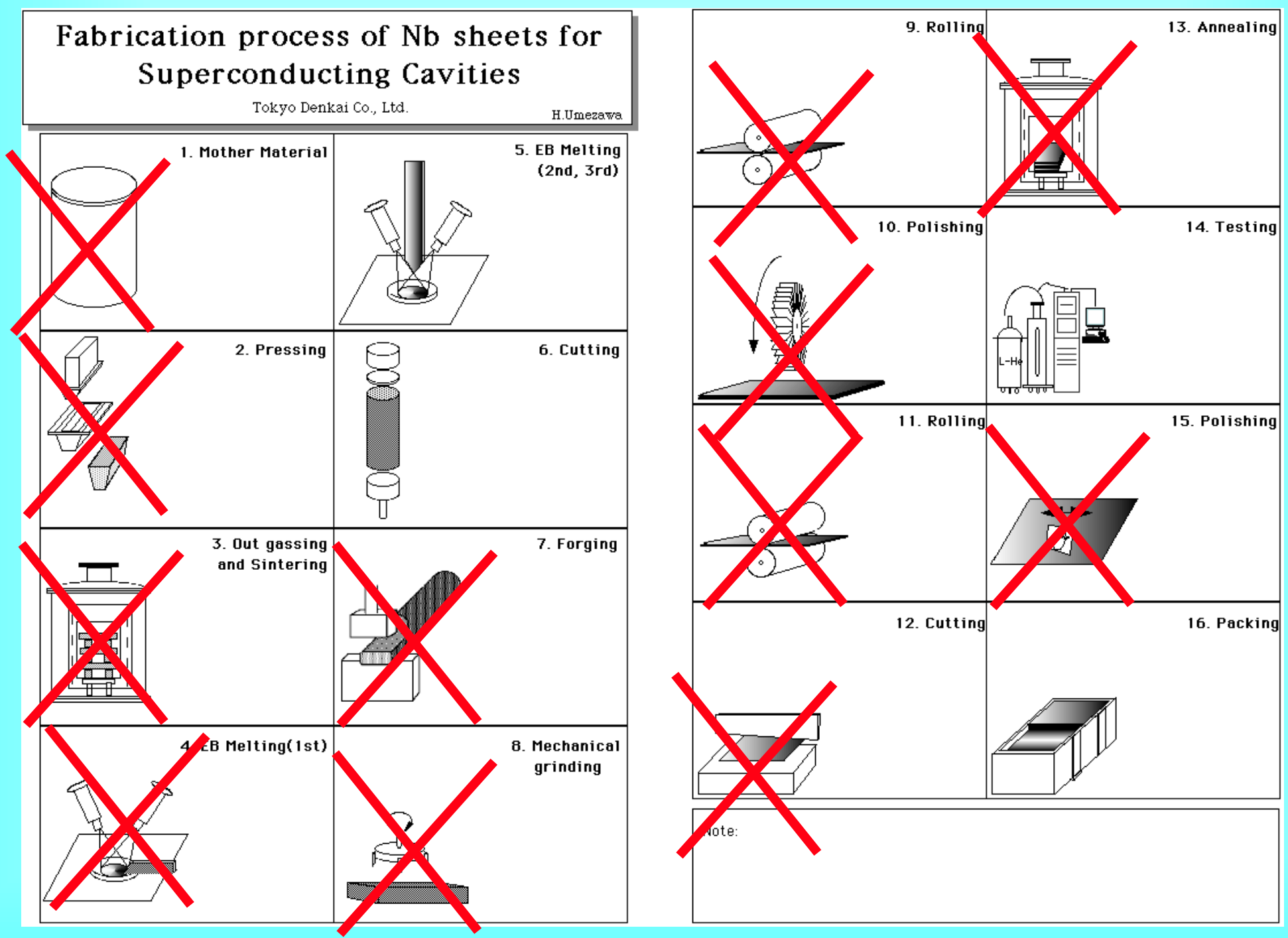

W.Singer, CARE06 Annual Meeting, Frascati, 15 -17 November 2006 


\section{Large grain/single crystal cavity}

\section{Possible advantages:}

- Cost effective

- Higher purity. RRR=600 in the ingot is achievable

- No danger that during many steps from ingot to sheet the material will be polluted.

- Simplified quality control (reduced number of measurements: grain size, eddy current scanning etc.)

- Higher thermal conductivity at low temperatures (phonon peak)

- Higher quality factor Q of the cavity is to expect (less RF losses on grain boundaries)

- Simplified cavity treatment (BCP instead EP) could be applied

- Less susceptible to field emission

- Baking at $120^{\circ} \mathrm{C}$ works better 


\section{DESY LG/SC R\&D program}

\begin{tabular}{c|c|c|c|c|c}
\hline $\begin{array}{c}\text { Material of the } \\
\text { company }\end{array}$ & RRR & No./Type & $\begin{array}{c}\text { Fabrication } \\
\text { by }\end{array}$ & Fabrication Procedure & $\begin{array}{c}\text { Status, September } \\
\mathbf{2 0 0 6}\end{array}$ \\
\hline Heraeus/LG & 500 & 1AC3 & ACCEL & Deep drawing + EB welding & $\begin{array}{c}\text { Tested after EP, tested } \\
\text { after BCP }\end{array}$ \\
\hline Heraeus/LG & 500 & 1AC4 & ACCEL & Deep drawing + EB welding & $\begin{array}{c}\text { Tested after EP, tested } \\
\text { after BCP }\end{array}$ \\
\hline Heraeus/LG & 500 & 1AC5 & ACCEL & Spinning + EB welding & Tested after EP and BCP \\
\hline CBMM/SC & 200 & 1AC6 & ACCEL & Spinning + EB welding & Tested after BCP and EP \\
\hline Heraeus/LG & 340 & 1AC7 & ACCEL & Deep drawing + EB welding & $\begin{array}{c}\text { Tested after BCP, In EP } \\
\text { treatment }\end{array}$ \\
\hline Heraeus/SC & 300 & 1AC8 & ACCEL & Deep drawing + EB welding & In BCP treatment \\
\hline Heraeus/LG & 300 & 1DE20 & DESY & Deep drawing + EB welding & Produced \\
\hline Heraeus/LG & 300 & 1DE21 & DESY & Deep drawing + EB welding & Produced \\
\hline Ningxia/LG & 400 & 1DE22 & DESY & Deep drawing + EB welding & Produced \\
\hline CBMM/LG & 250 & 1DE25 & DESY & Deep drawing + EB welding & In fabrication \\
\hline NPC/LG & 240 & 1DE26 & DESY & Deep drawing + EB welding & In fabrication \\
\hline Heraeus/LG & 340 & AC114 & ACCEL & Deep drawing + EB welding & Tested after BCP \\
\hline Heraeus/LG & 370 & AC113 & ACCEL & Deep drawing + EB welding & Tested after BCP \\
\hline Heraeus/LG & 500 & AC112 & ACCEL & Deep drawing + EB welding & Tested after BCP \\
\hline
\end{tabular}

W.Singer, CARE06 Annual Meeting, Frascati, 15 -17 November 2006 


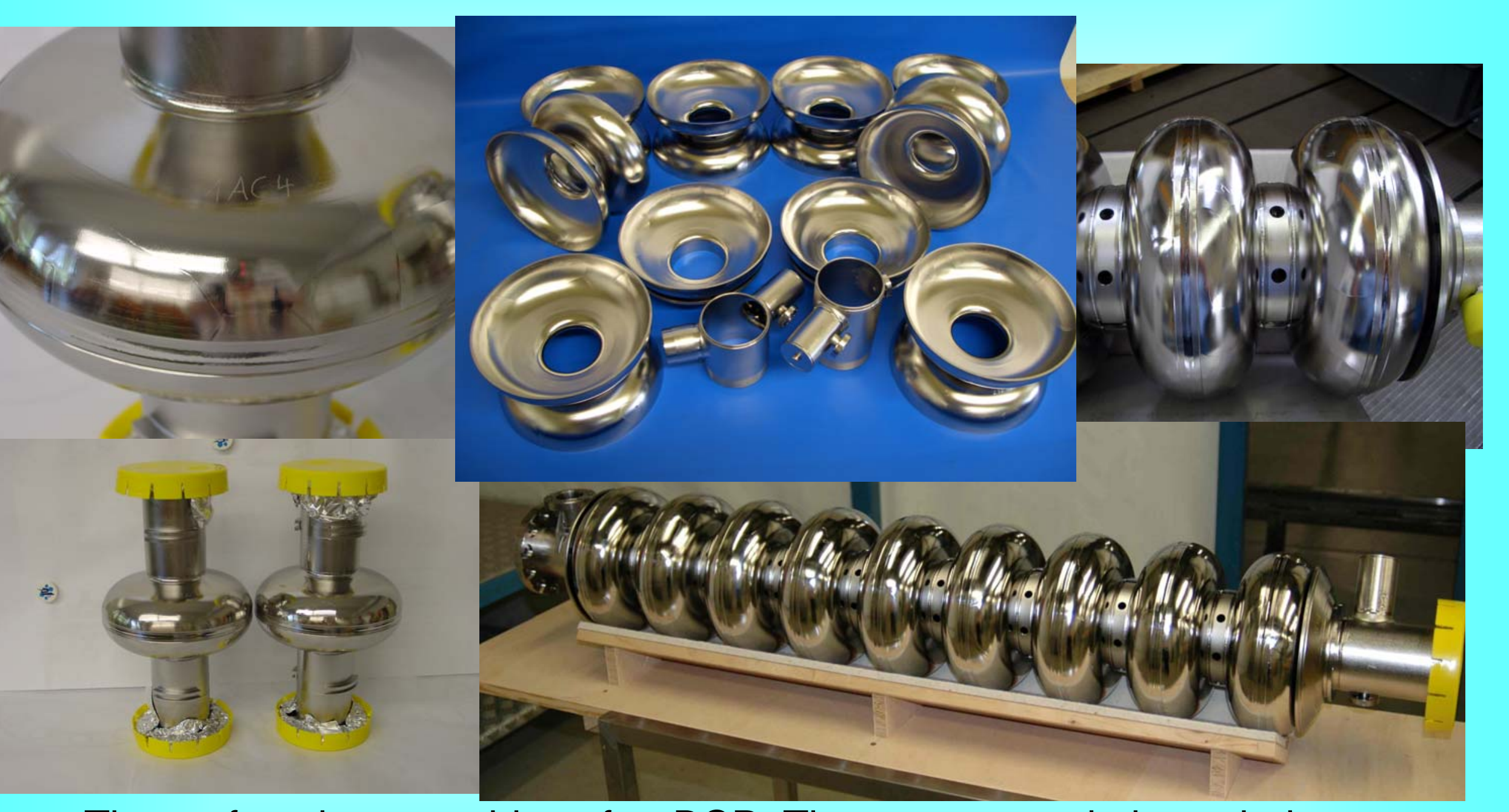

The surface is more shiny after BCP. The steps at grain boundaries are more pronounced as in polycrystalline material. 


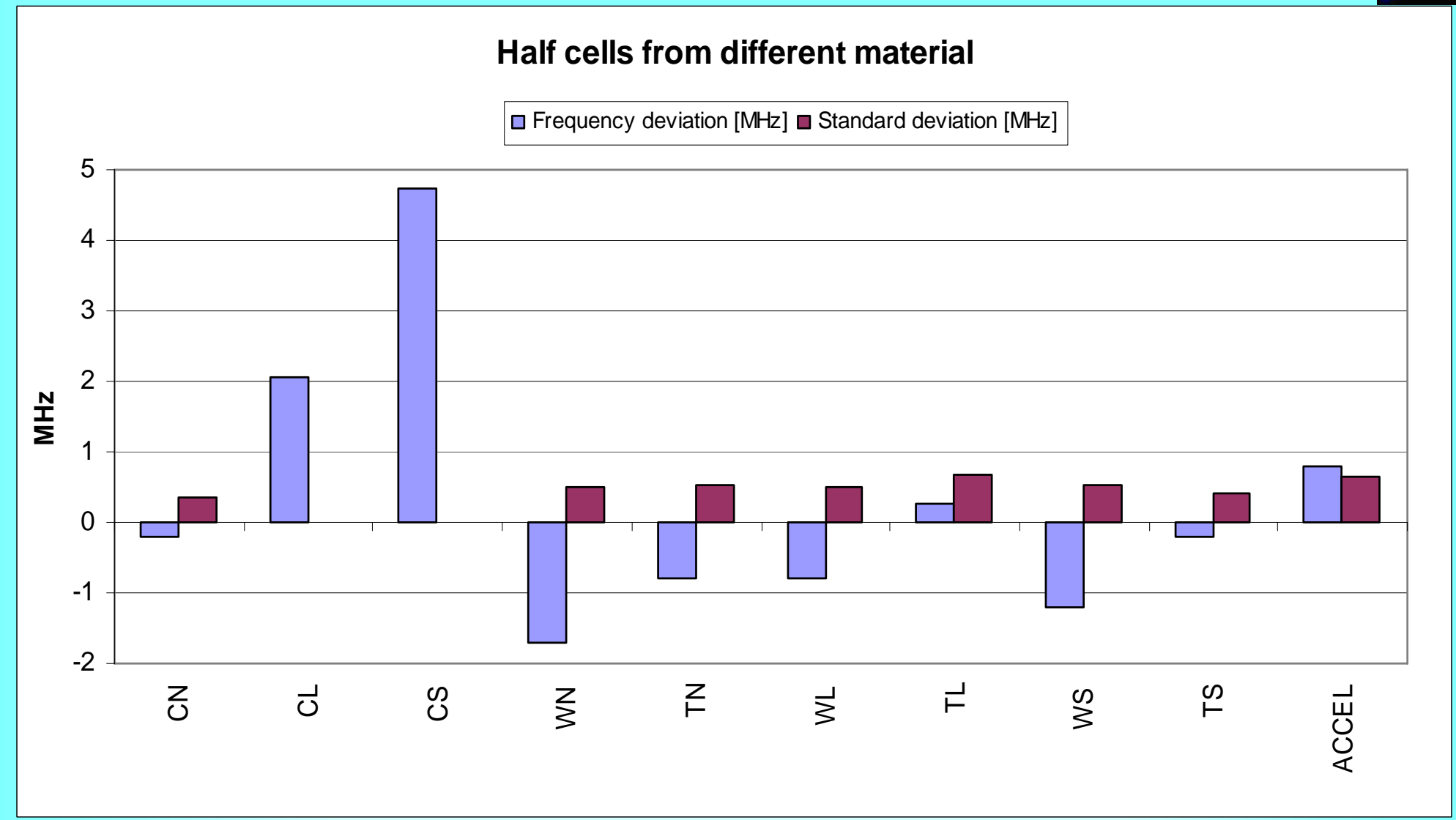

Frequency measurement of 6 end half cells ( $L$ and $S$ ) and 48 middle half cells (N) for cavities AC112-114. C - large crystal, W - Wah Chang, T Tokyo Denkai. The shape conformity of half cells from large grain material is lower as of conventional fine grain (could be improved by correction of the tools), the uniformity of the half cells from large grain material is better. 


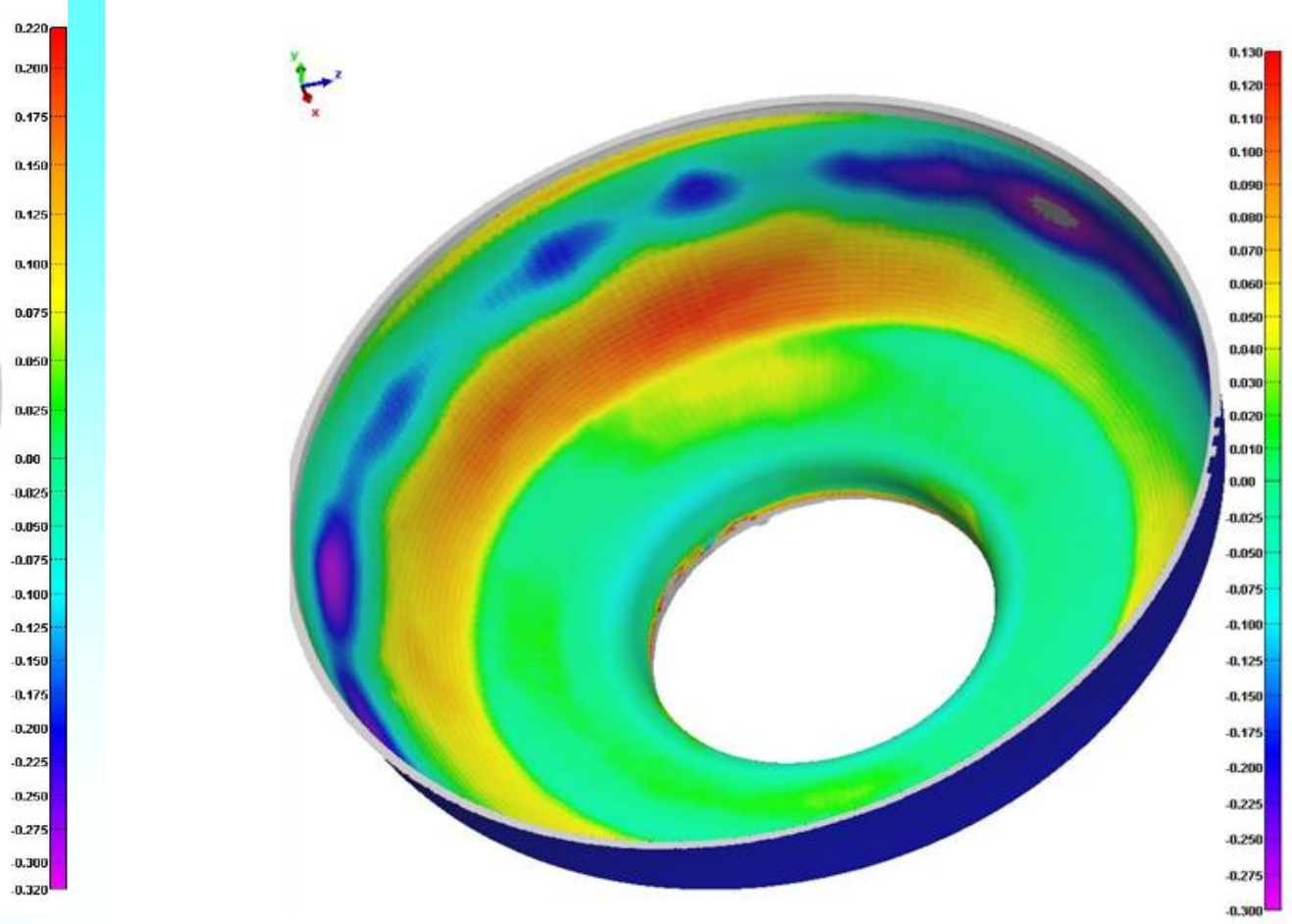

3D Image of the optical measurement of the shape on large grain half cell (left; realized accuracy $+0,22$ / $-0,32 \mathrm{~mm}$ ) in comparison with a fine grain half cell (right; realized accuracy $+0,13 /-0,30 \mathrm{~mm}$ ). The large grains are fractionally pronounced. The variation of the large grain half cell shape is somewhat larger 


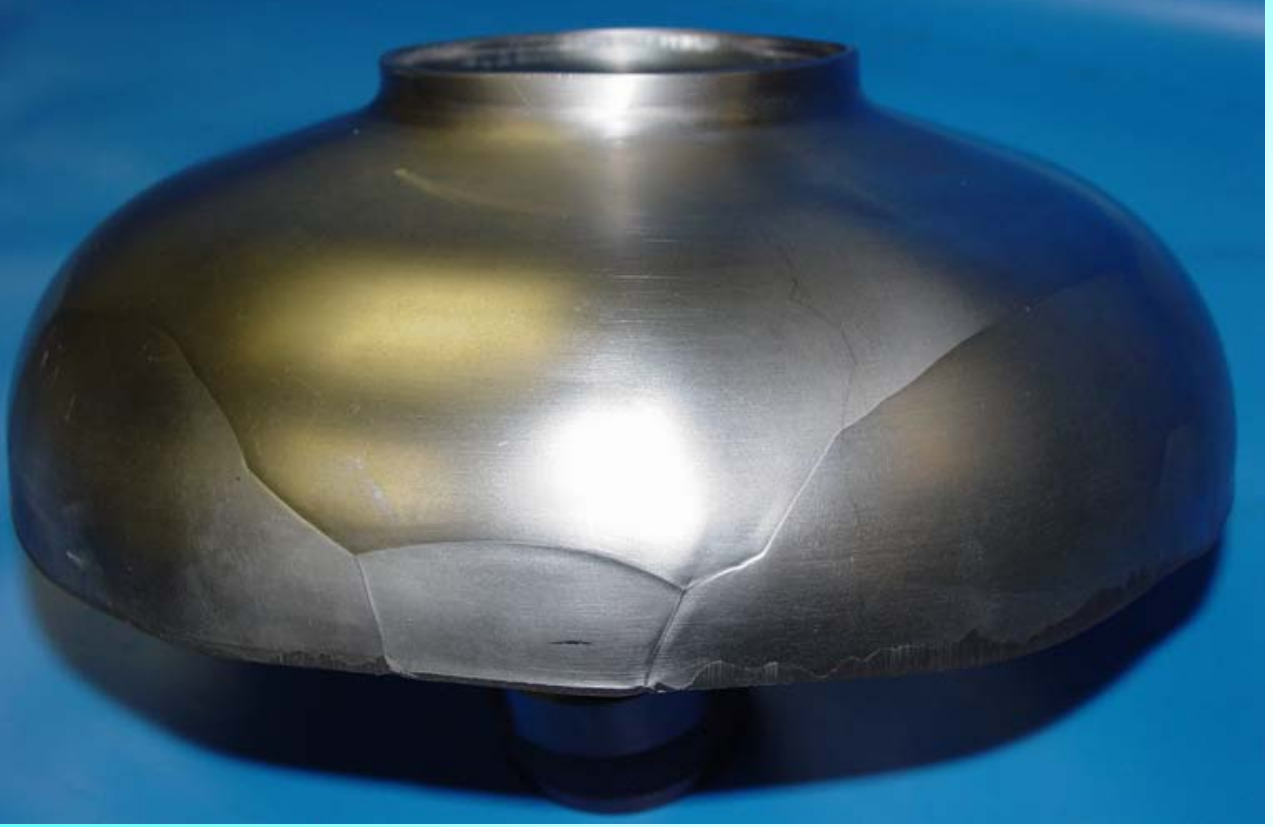

Deep drawn half cell of HERAEUS large grain niobium; Large single crystal at centre, no problems on iris area

Deep drawn half cells of Ningxia LG $\mathrm{Nb}$; necking of the wall thickness at iris on grain boundaries 
1AC3EP-tr eatment af ter bake

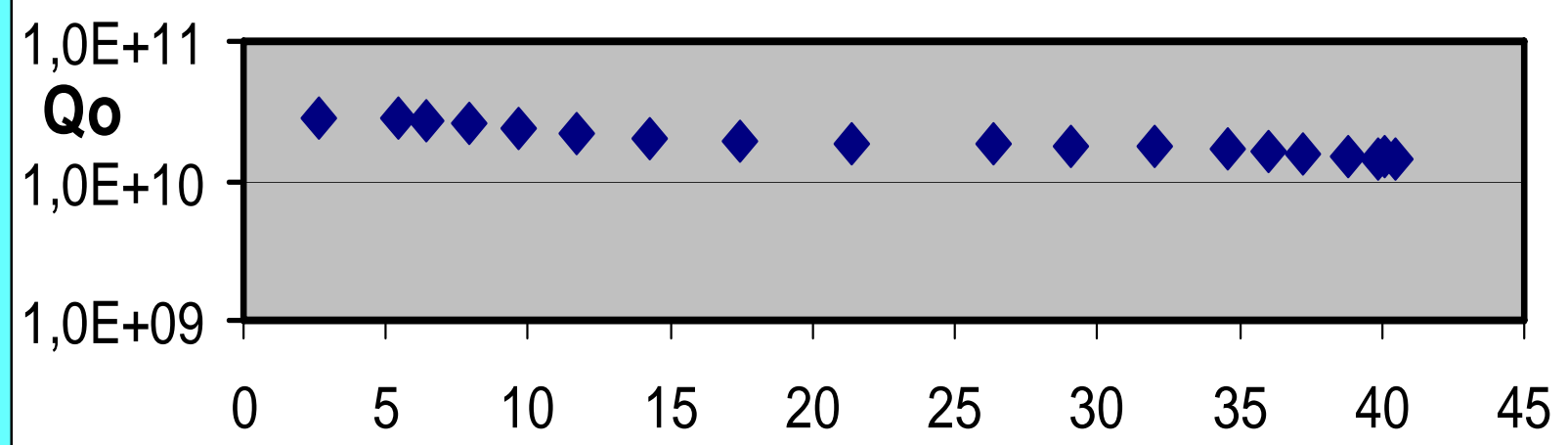

Eacc, $M V / m$

$\multimap \mathrm{AC114} \curvearrowleft \mathrm{AC112} \leftarrow \mathrm{AC113}$

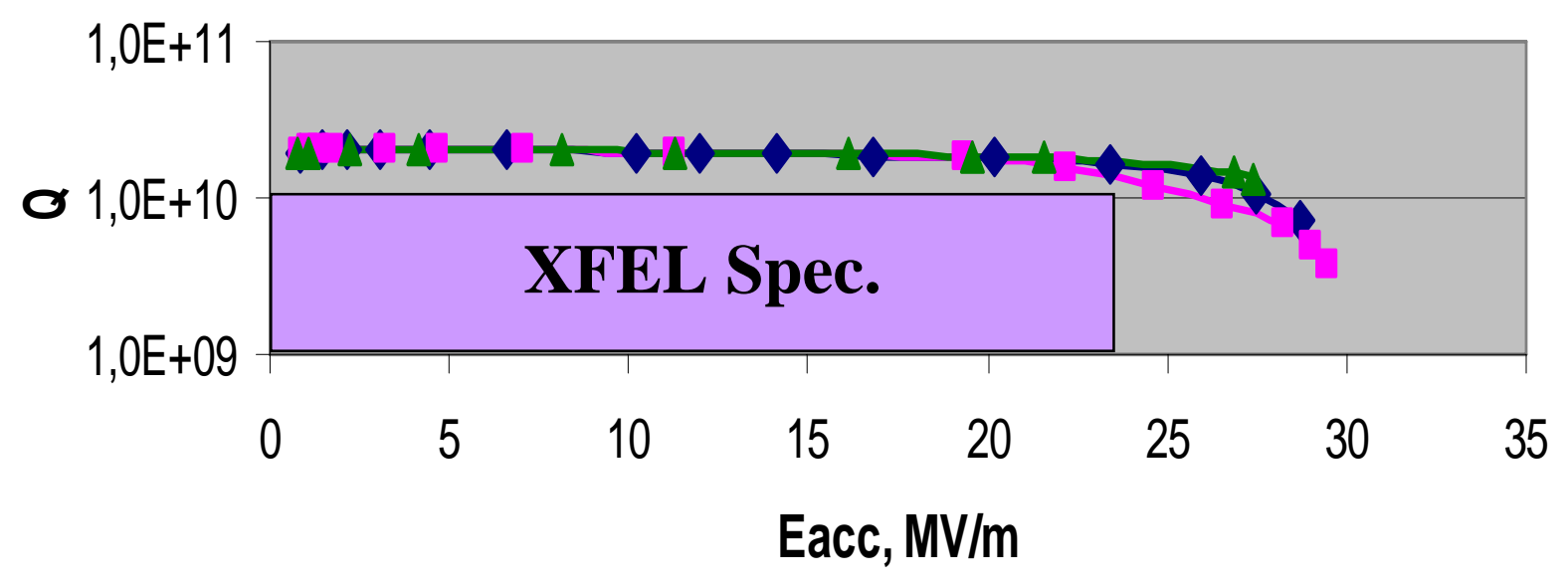

$\mathrm{Q}$ (Eacc) curve of the large grain single cell cavity $1 \mathrm{AC} 3$ after EP and BCP treatment

First test Q(Eacc) curve of the large grain nine cell cavities AC112AC114 after BCP treatment 
- TTF, $800^{\circ} \mathrm{C}+\mathrm{BCP} \backsim \mathrm{LG} 9$-cell, $800^{\circ} \mathrm{C}+\mathrm{BCP}$

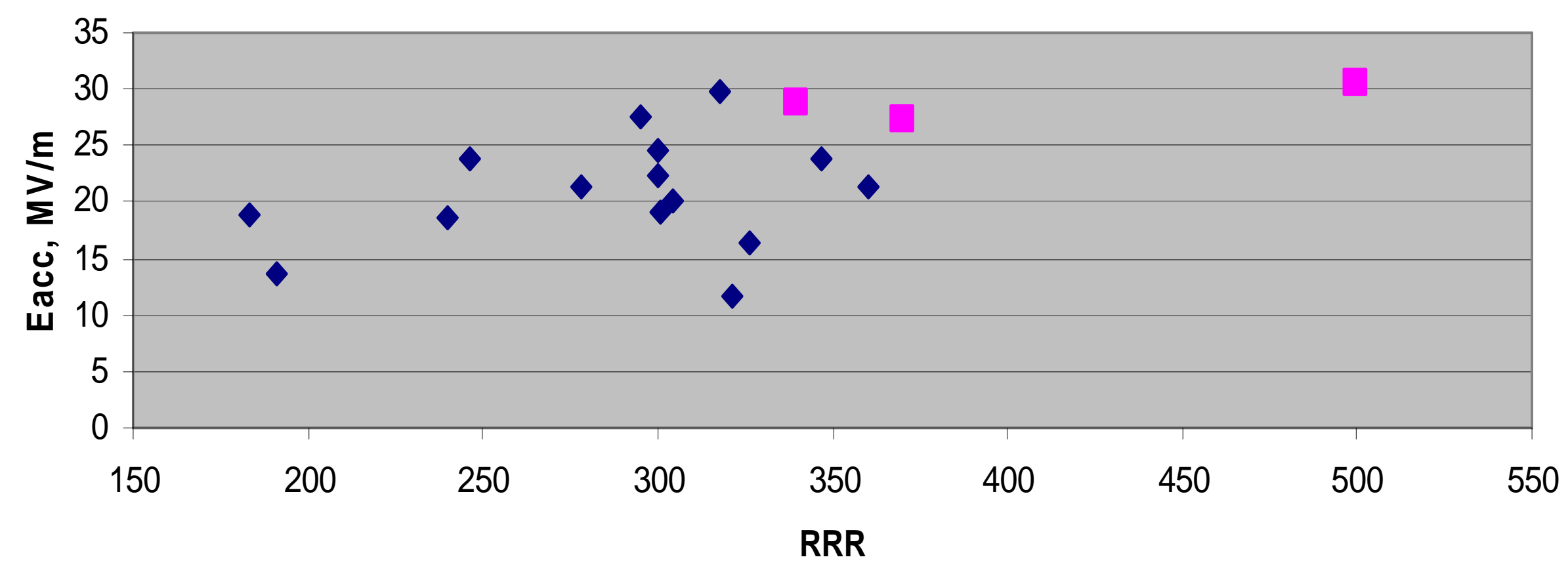

Comparison of the Eacc performance of large grain (LG) 9-cell cavities with similarly treated TTF cavities 


\begin{tabular}{|c|c|c|c|c|c|}
\hline $\begin{array}{l}\text { Material of the } \\
\text { company }\end{array}$ & No./Type & Treatment & $\begin{array}{l}\text { Eacc, } \\
\text { MV/m }\end{array}$ & $\begin{array}{c}\text { Qo at } \\
\text { Eacc }=23.5\end{array}$ & Limitation \\
\hline $\begin{array}{l}\text { Heraeus/large } \\
\text { grain }\end{array}$ & $\begin{array}{c}\text { 1AC3/single } \\
\text { cell }\end{array}$ & $\begin{array}{c}190 \mu \mathrm{m} \text { EP, } 800^{\circ} \mathrm{C} 2 \mathrm{~h}, \\
120^{\circ} \mathrm{C} 48 \mathrm{~h}, \mathrm{HPR}\end{array}$ & 41.2 & $3.2 \mathrm{E}+10$ & $\begin{array}{l}\text { Quench at } \\
\text { equator }\end{array}$ \\
\hline $\begin{array}{l}\text { Heraeus/large } \\
\text { grain }\end{array}$ & $\begin{array}{c}\text { 1AC4/single } \\
\text { cell }\end{array}$ & $\begin{array}{c}190 \mu \mathrm{m} \text { EP, } 800^{\circ} \mathrm{C} 2 \mathrm{~h}, \\
128^{\circ} \mathrm{C} 48 \mathrm{~h}, \mathrm{HPR}\end{array}$ & 38.5 & $2.3 \mathrm{E}+10$ & $\begin{array}{l}\text { Quench at } \\
\text { equator }\end{array}$ \\
\hline $\begin{array}{c}\text { Heraeus/large } \\
\text { grain (spinning) }\end{array}$ & $\begin{array}{c}1 \mathrm{AC} 5 / \text { single } \\
\text { cell }\end{array}$ & $\begin{array}{c}275 \mu \mathrm{m} \mathrm{EP}+\mathrm{BCP}, \\
800^{\circ} \mathrm{C} 2 \mathrm{~h}, 135^{\circ} \mathrm{C} 48 \mathrm{~h}, \\
\mathrm{HPR}\end{array}$ & 29.7 & $2.0 \mathrm{E}+10$ & $\begin{array}{l}\text { Quench, not } \\
\text { equator }\end{array}$ \\
\hline $\begin{array}{l}\text { Heraeus/large } \\
\text { grain }\end{array}$ & $\begin{array}{c}1 \mathrm{AC} 7 / \text { single } \\
\text { cell }\end{array}$ & $\begin{array}{l}220 \mu \mathrm{m} \mathrm{BCP}, 800^{\circ} \mathrm{C} \\
2 \mathrm{~h}, 120^{\circ} \mathrm{C} 48 \mathrm{~h}, \mathrm{HPR}\end{array}$ & 25.3 & $3.0 \mathrm{E}+10$ & $\begin{array}{l}\text { Quench (no } \\
\text { TM) }\end{array}$ \\
\hline $\begin{array}{l}\text { Heraeus/large } \\
\text { grain }\end{array}$ & $\begin{array}{l}\text { AC112/nine } \\
\text { cell }\end{array}$ & $\begin{array}{c}200 \mu \mathrm{m} \text { BCP, } 800^{\circ} \mathrm{C}, \\
\mathrm{HPR}\end{array}$ & 30,5 & $2.0 \mathrm{E}+10$ & $\begin{array}{c}\text { Field Emission } \\
\text { FE }\end{array}$ \\
\hline $\begin{array}{l}\text { Heraeus/large } \\
\text { grain }\end{array}$ & $\begin{array}{l}\text { AC113/nine } \\
\text { cell }\end{array}$ & $\begin{array}{c}160 \mu \mathrm{m} \mathrm{BCP}, 800^{\circ} \mathrm{C}, \\
\mathrm{HPR}\end{array}$ & 27,4 & $2.0 \mathrm{E}+10$ & Quench \\
\hline $\begin{array}{l}\text { Heraeus/large } \\
\text { grain }\end{array}$ & $\begin{array}{l}\text { AC114/nine } \\
\text { cell }\end{array}$ & $\begin{array}{c}120 \mu \mathrm{m} \mathrm{BCP}, 800^{\circ} \mathrm{C}, \\
\mathrm{HPR}\end{array}$ & 28.7 & $2.1 \mathrm{E}+10$ & $\begin{array}{c}\text { Quench } \\
\text { probably FE } \\
\text { induced }\end{array}$ \\
\hline
\end{tabular}


Grain boundaries GBs contribute to reduction of the cavity performance

- responsible for magnetic field enhancement (steps on GBs after BCP)

- make easier the penetration of external magnetic field (GBs are planar weak links with reduced critical current density)

- additional RF resistance due to vortices penetrating along the grain boundary (reduce the quality factor Qo)

- make easier the hydrogen absorption and diffusion

- gathered impurities (reduced RRR)

- reduce the thermal conductivity at low temperatures (reduced phonon contribution)

- possibly make worse the baking (oxides and impurities in grain boundaries)

- possibly make worse high pressure water rinsing (enhance the surface roughness)

Fine grain $\mathrm{Nb}$ sheet corresponds to length $\sim 3000 \mathrm{~m}$, LG

Niobium corresponds to length $\sim 3 \mathrm{~m}$ 


\section{Dream:}

\section{Single Crystal}




\section{P.Kneisel, JLab}

\section{HG Cavity Shape:2.3 GHz}

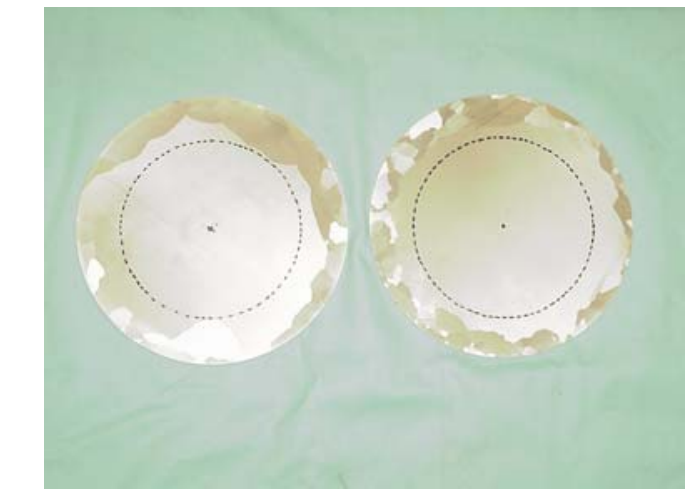

$E_{\text {peak }} / E_{\text {acc }}=1.674$

$H_{\text {peak }} / E_{\text {acc }}=4.286 \mathrm{mT} / \mathrm{MV} / \mathrm{m}$

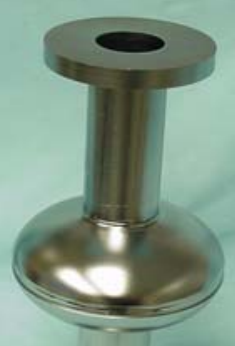

ar

\section{ILC LL cavity Shape:2.3 GHz}

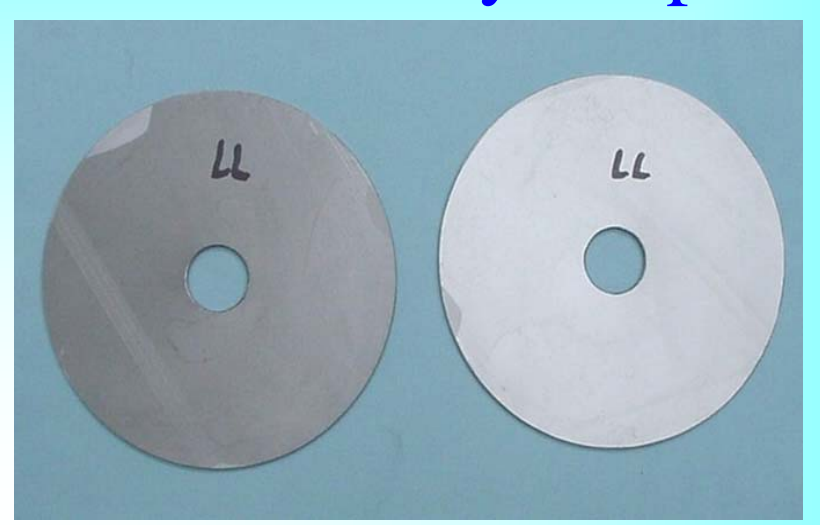

$$
\begin{aligned}
& E_{\text {peak }} / E_{\text {acc }}=2.072 \\
& H_{\text {peak }} / E_{\text {acc }}=3.56 \mathrm{mT} / \mathrm{MV} / \mathrm{m}
\end{aligned}
$$

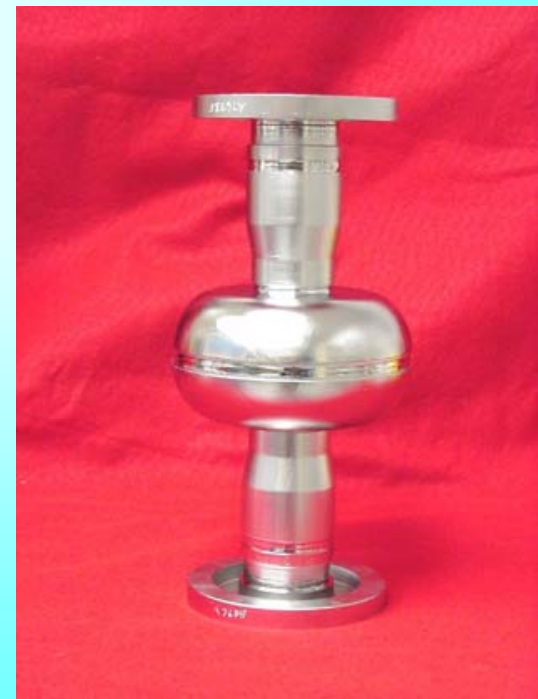

W.Singer, CARE06 Annual Meeting, Frascati, 15 -17 November 2006 


\section{Single-crystal cavities}

2.3 GHz single-cells, treated by BCP

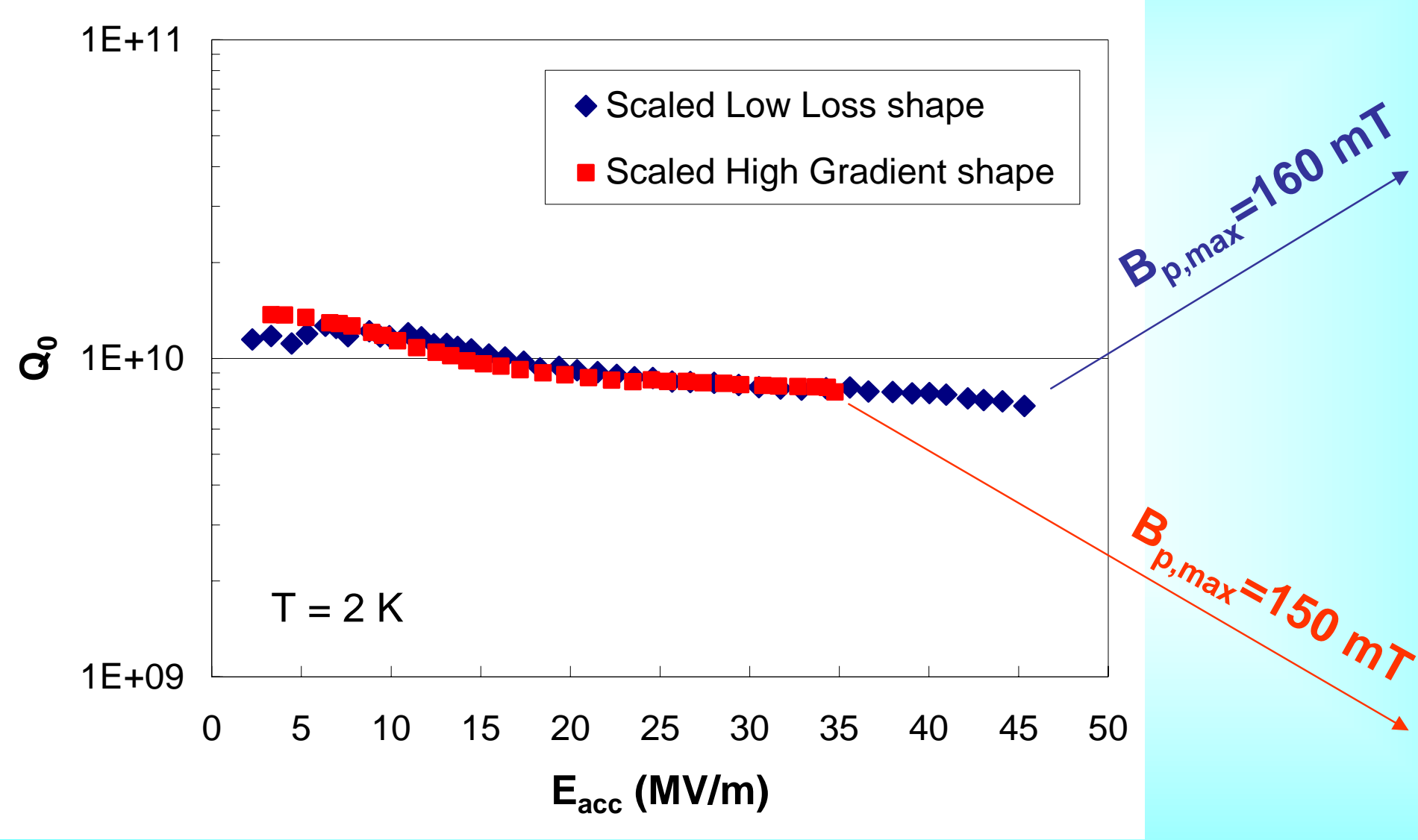

P. Kneisel et al., Proc. of PAC'05, Knoxville, $T N, 2005$, p. 399 


\section{Is it possible produce single crystal cavities of dimensions required for ILC?}

Fabrication of TESLA shape single crystal single cell cavities proposed.

Following aspects have been investigated and taken into consideration during cavity fabrication

- Definite enlargement of the discs diameter is possible without destroying the single crystal structure in an existing state.

- Appropriate heat treatment will not destroy the deformed single crystal

- The single crystals keep the crystallographic structure and the orientations after deep drawing and annealing at $800^{\circ} \mathrm{C}$

- Two single crystals will grow together by EB welding, if the crystal orientations is taken into account. 


\section{What deformation degree can withstand the SC?}
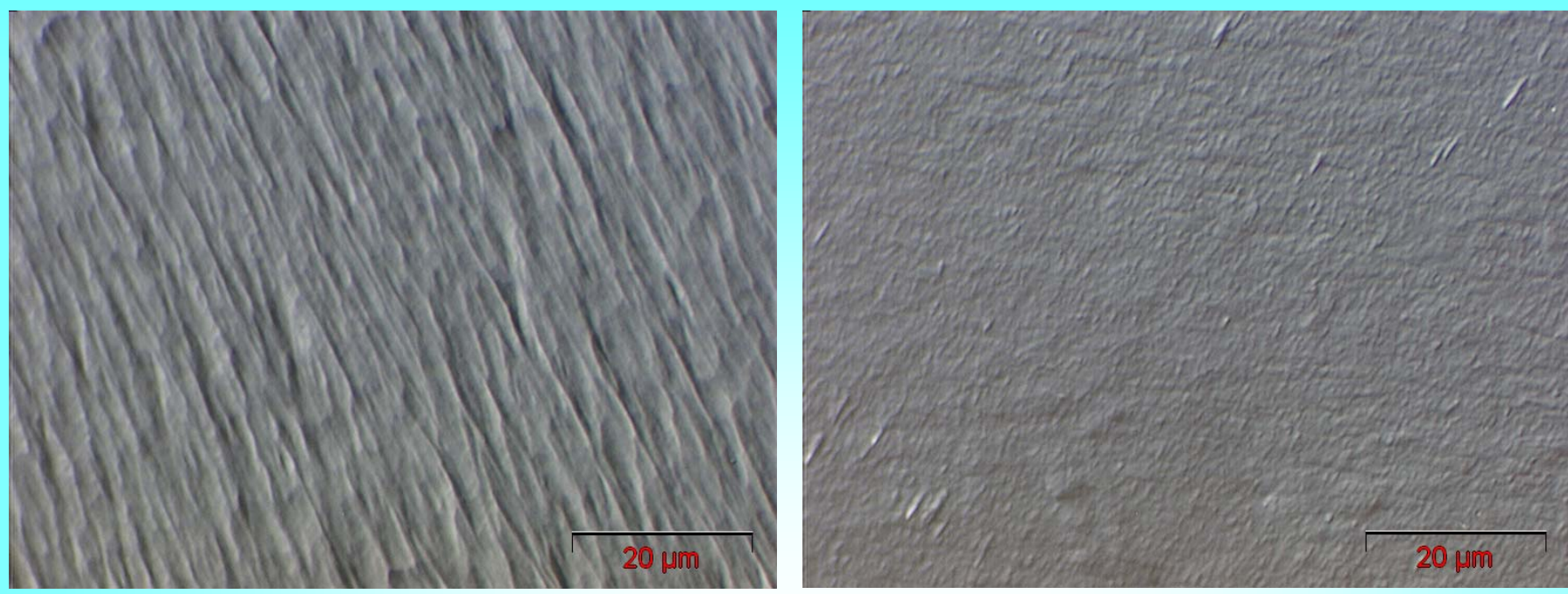

$\mathrm{Nb}$ single crystal after deformation degree of $60 \%$ (left) and annealing (right)
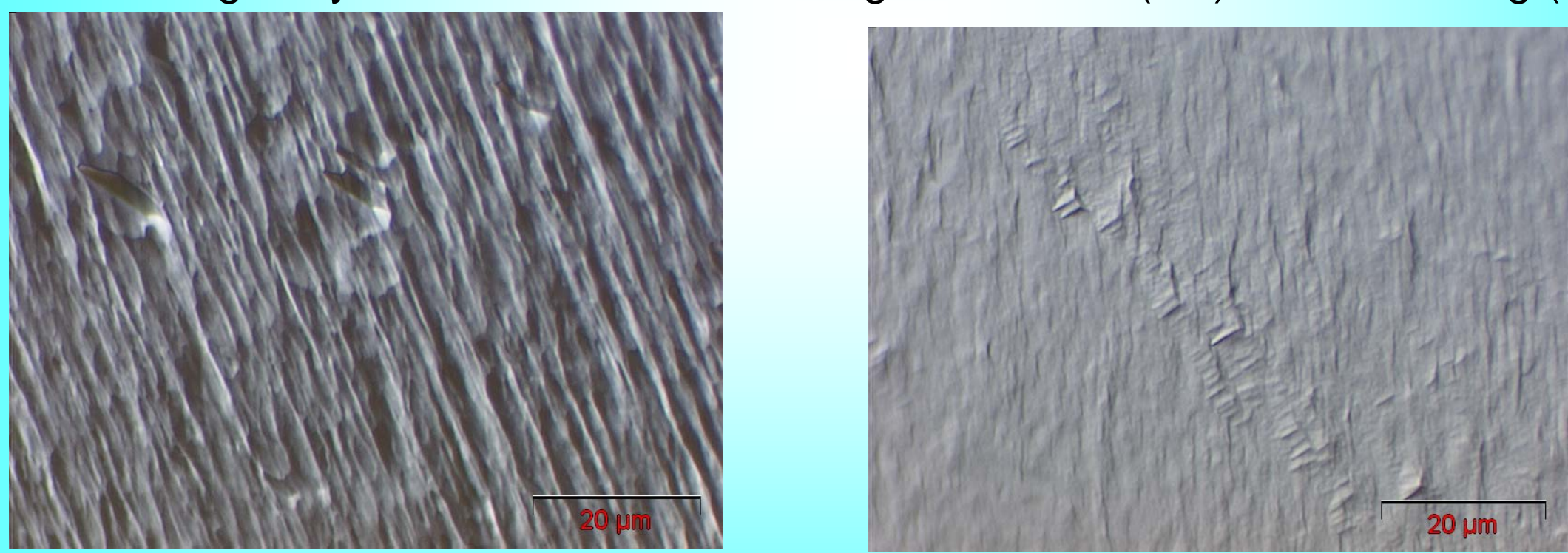

$\mathrm{Nb}$ single crystal after deformation degree of $70 \%$ (left) and annealing (right) 


\section{Single crystals keep the crystallographic structure and the orientations after deep drawing and annealing at $800^{\circ} \mathrm{C}$}

X-Ray reflexes of the central crystal $\mathrm{K} 1$ in the flat disc. Orientation (100)

$\mathrm{X}$-Ray reflexes of $\mathrm{K} 1$ on position 1 before (above) and after annealing at

Position 1 ca. 20 $800^{\circ} \mathrm{C}, 2 \mathrm{hs}$ $\mathrm{mm}$ from iris

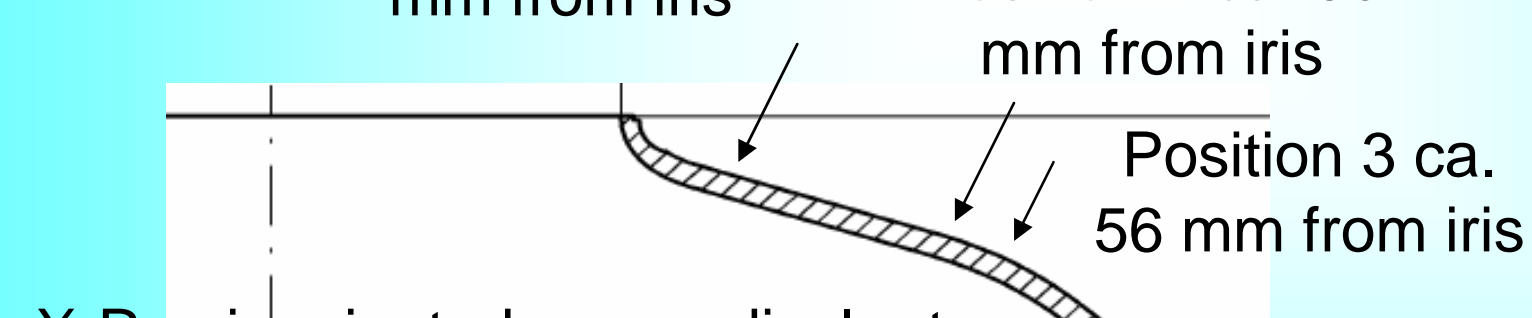

X-Ray is oriented perpendicular to the outside surface

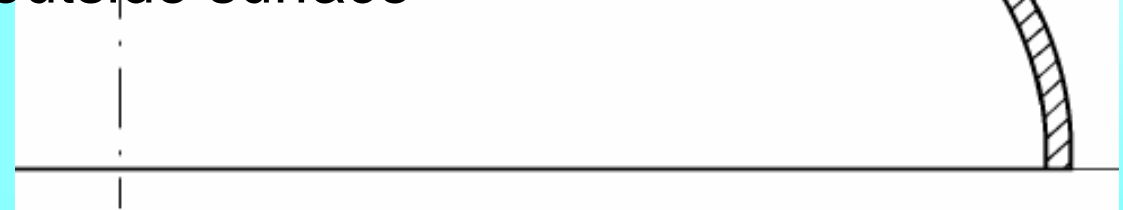

Determination of orientations of M. Spiwek (HASYLAB)
$\mathrm{X}$-Ray reflexes of $\mathrm{K} 1$ on position 2 before (above) and after annealing at $800^{\circ} \mathrm{C}, 2 \mathrm{hs}$ 


\section{Electron beam welding}
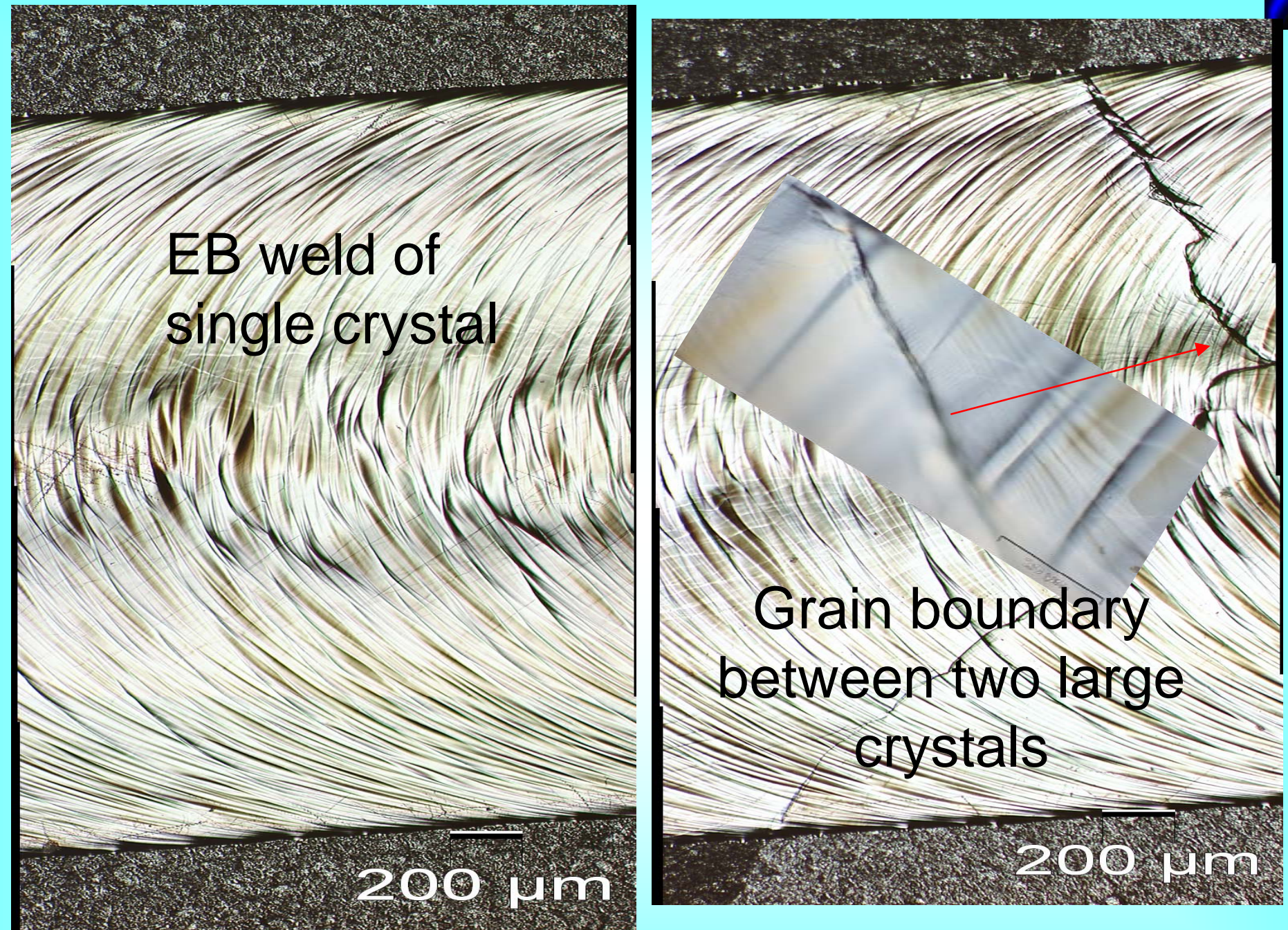

It seems that no new grains appear in the EB welding area, but the grain boundary remains 
In the appropriate EB welding the single crystals can grow together

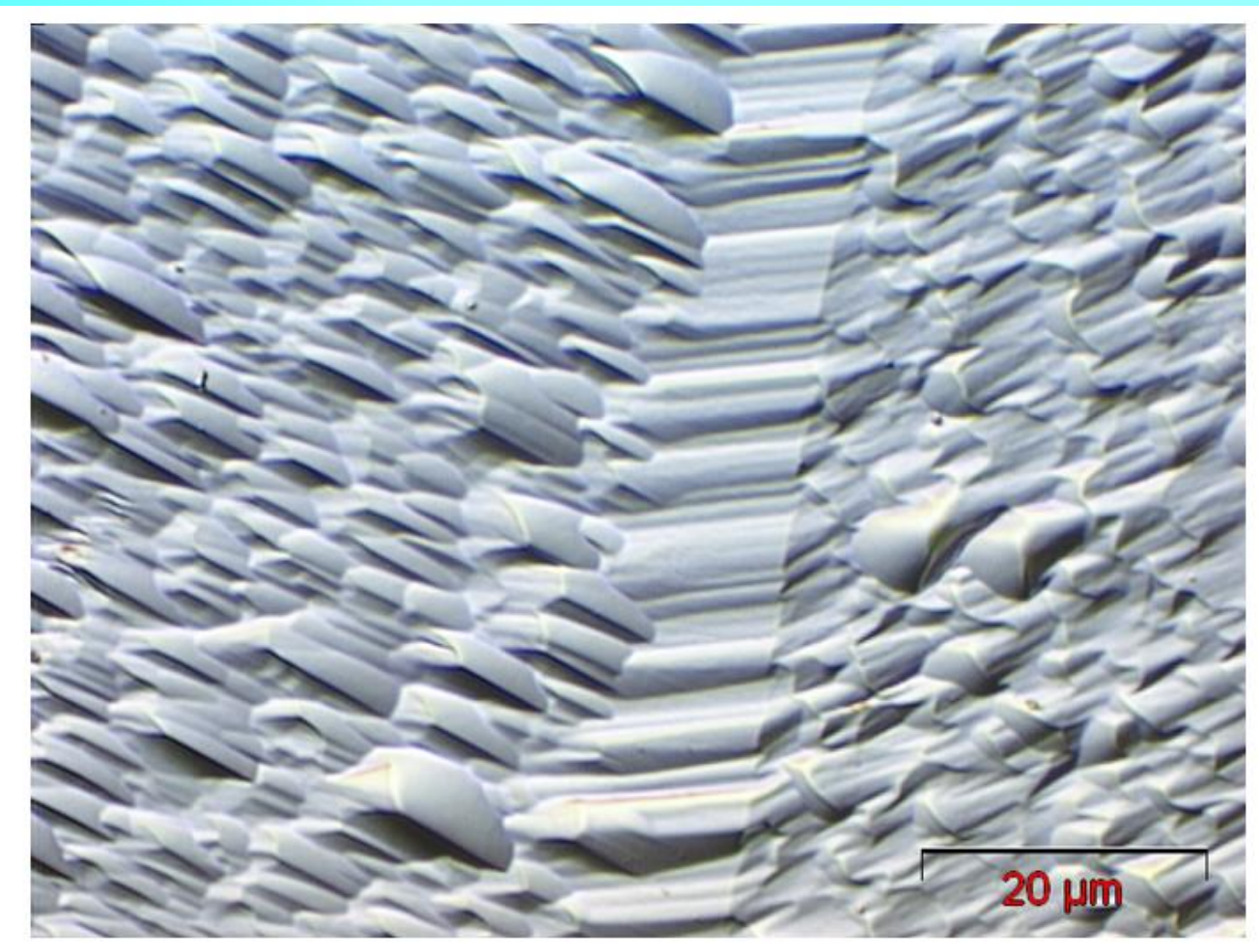

Left: Electron beam welding connection of two single crystals without regarding of crystals orientation (the grain boundary is pronounced)

Right: EB welding connection of

two single crystals after assembling considering the crystal orientation (the grain boundary is absent)

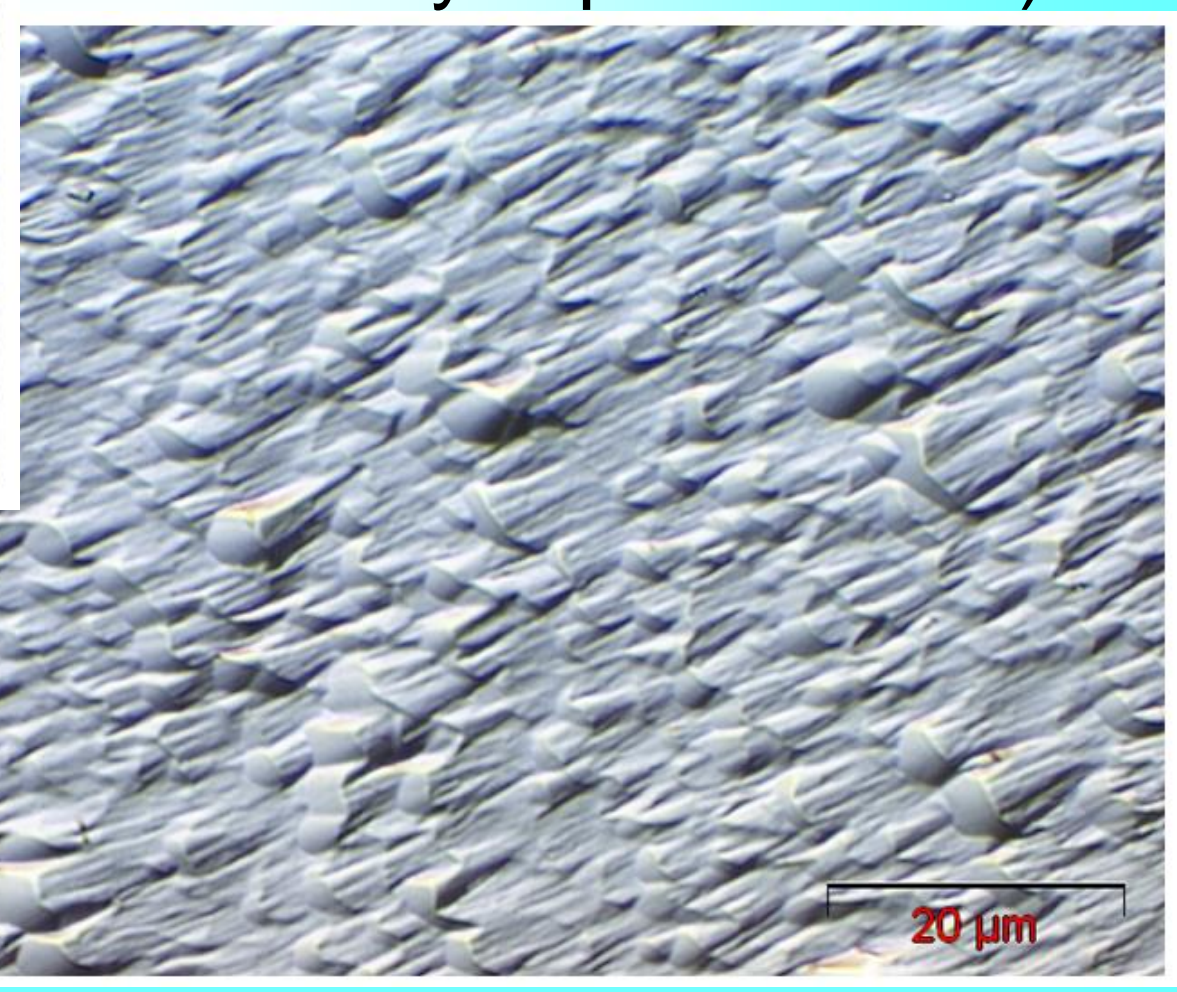

W.Singer, CARE06 Annual Meeting, Frascati, 15 -17 November 2006 


\section{EB welding seam}

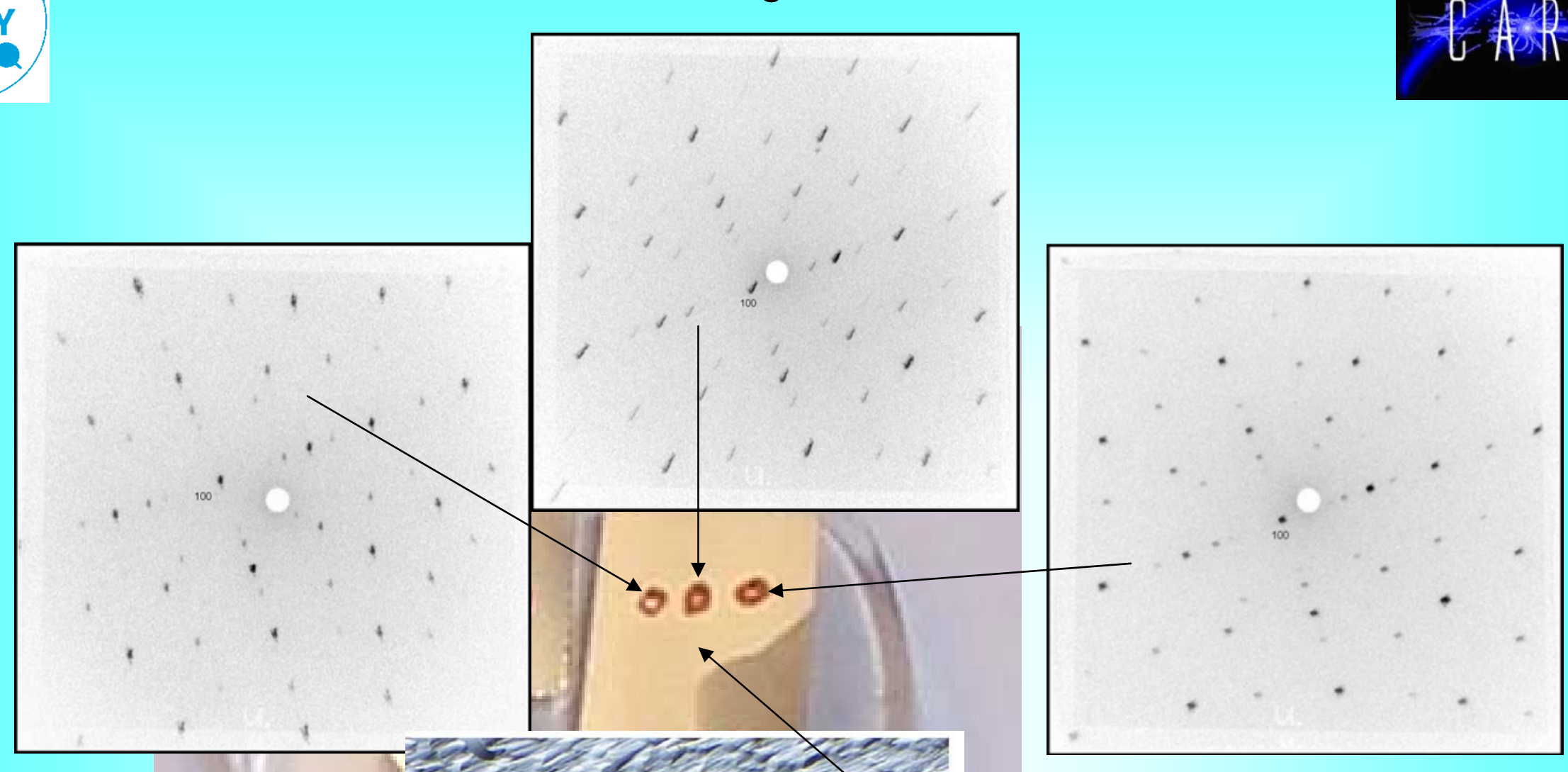

Left crystal

Right crystal

EB welding connection

X-Ray reflexes are the same in both welded together crystals and in the welding seam

W.Singer, CARE06 Annual Meeting, Frascati, 15 -17 November 2006 


\section{Single crystal cavity fabrication}
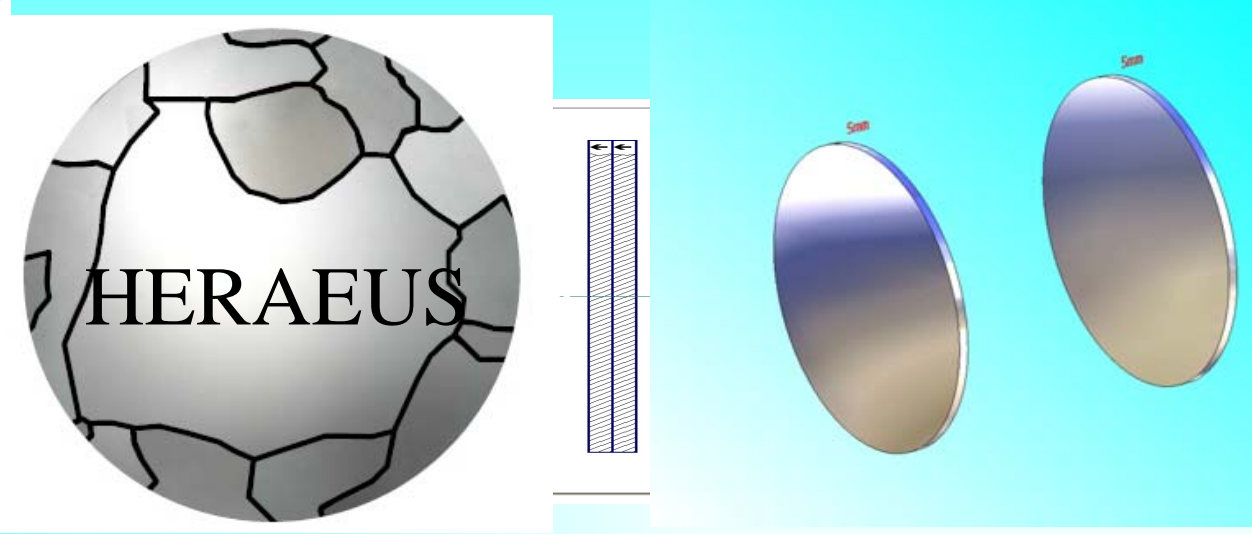

2-3.Cutting through the

1. Take out central single crystal of definite thickness diameter by special rolling

disc and increasing of deflnite thickness
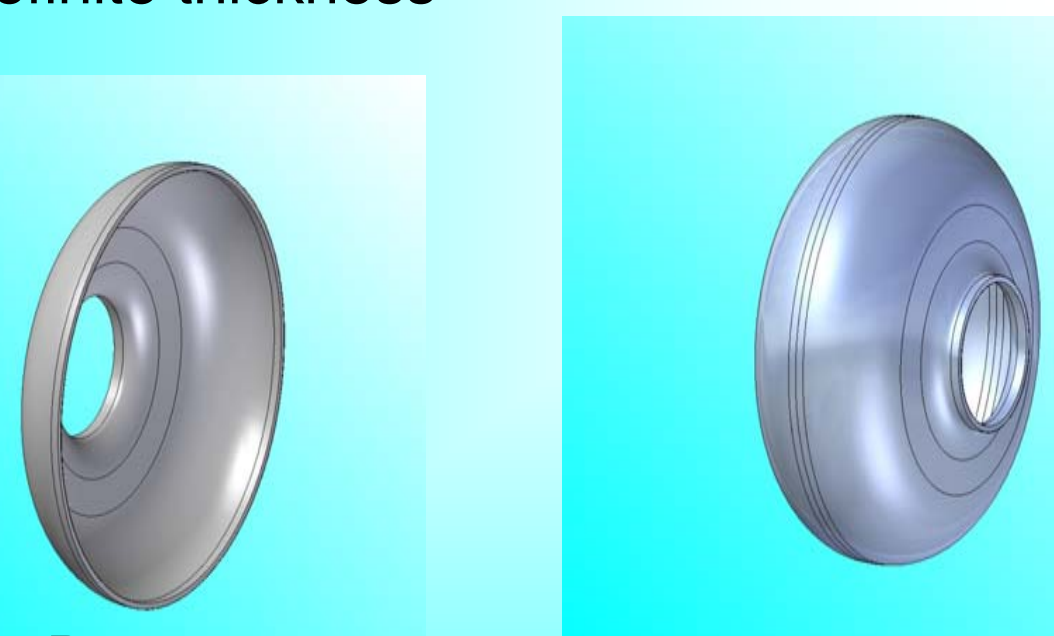

\section{Single crystals after deep drawing at ACCEL}

4. Deep

drawing

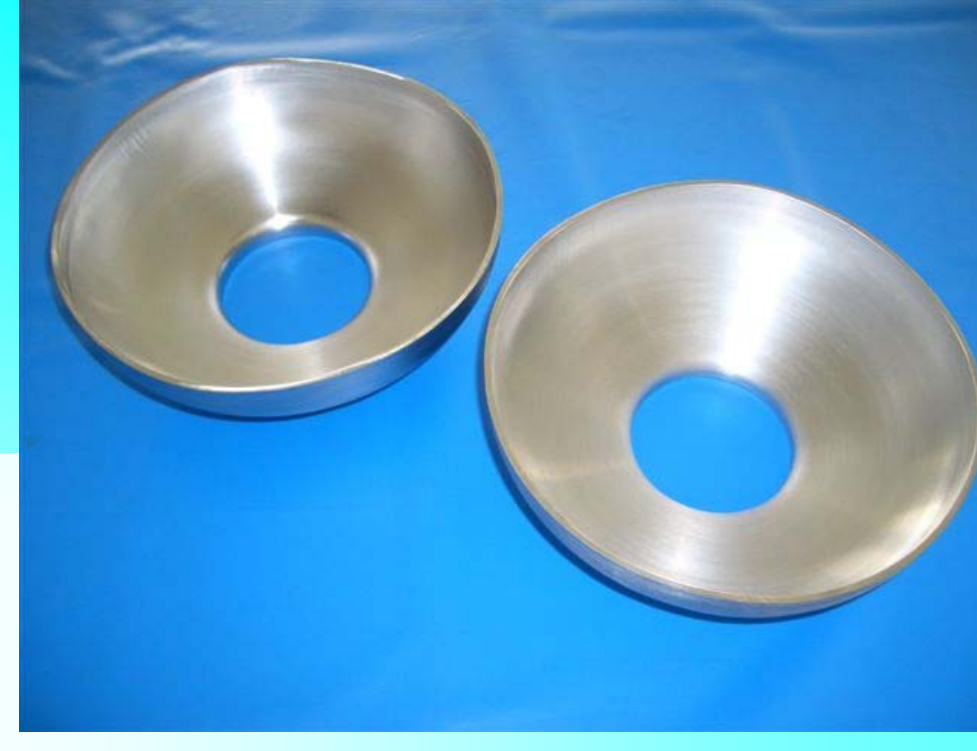

5. EB welding considering the crystal orientation 


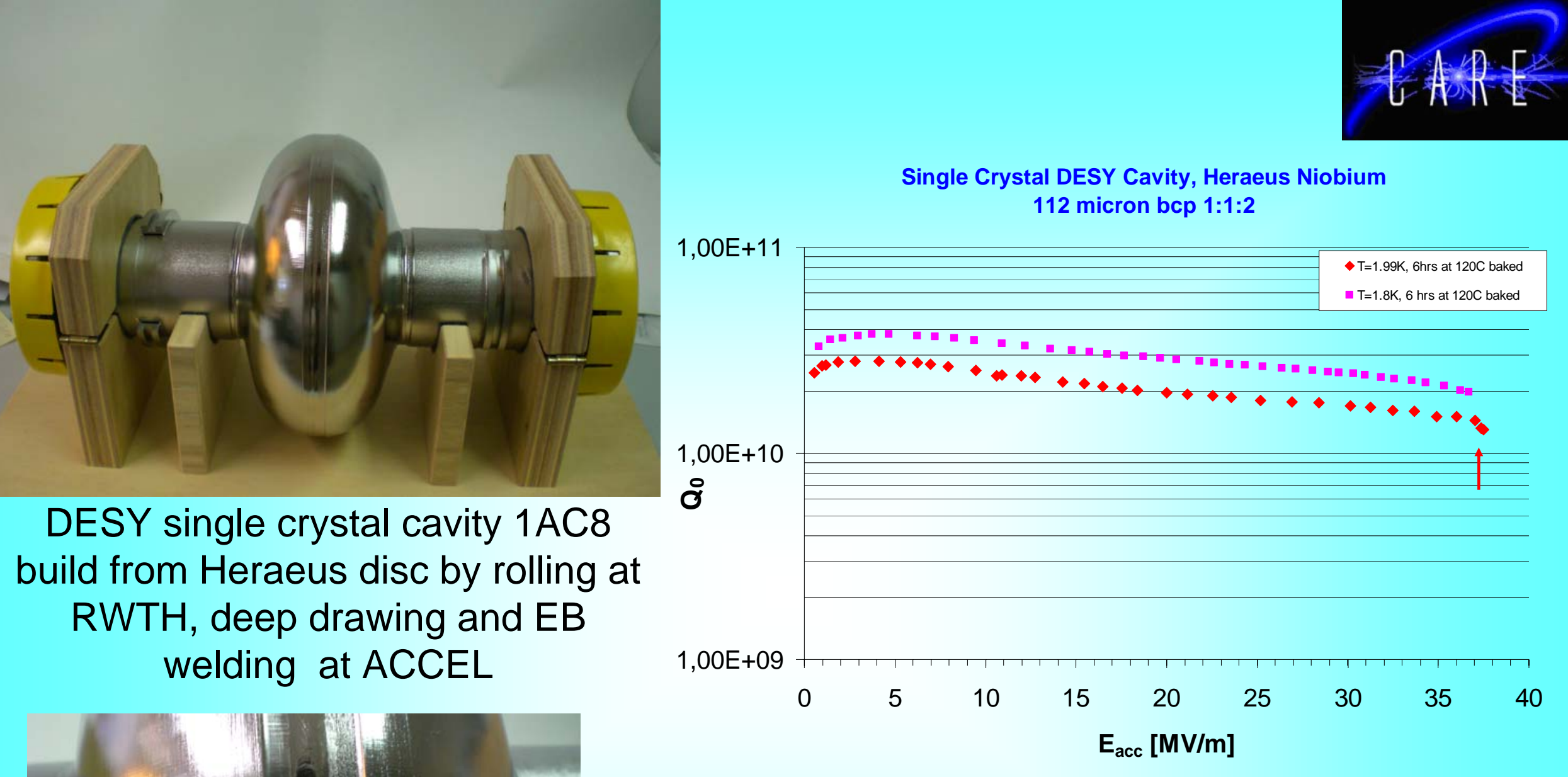

\section{Q(Eacc) curve after only $112 \mu \mathrm{m} \mathrm{BCP}$ and in situ baking $120^{\circ} \mathrm{C}$ for $6 \mathrm{hrs}$.}

\section{Preparation and RF tests of P.Kneisel, JLab}




\section{SC. It works. The proposed method can be extended on fabrication of multi cell cavities.}
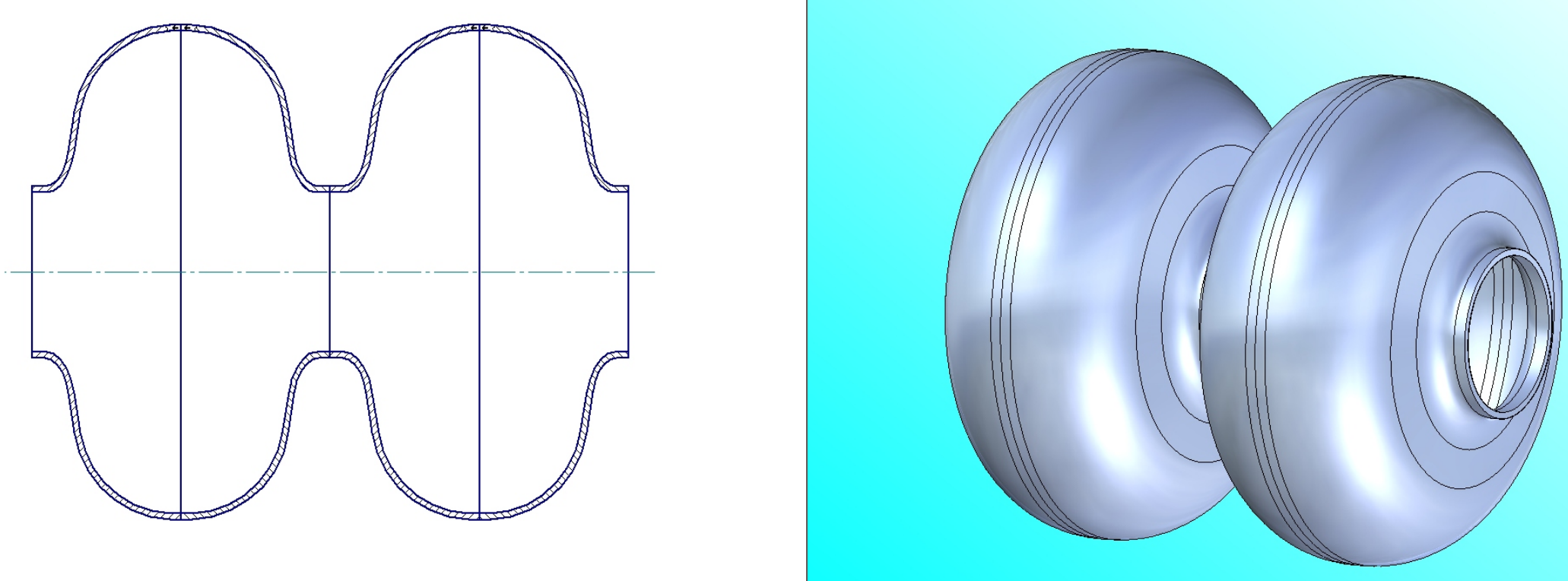
Thermal conductivity

$\mp$ Heraeus SC (100), RRR538

$\rightarrow$ Heraeus SC (110), RRR527

$\rightarrow$ Wah Chang, Fine Grain, RRR531 $\rightarrow-$ Heraeus two LG(110)/(111), RRR469

$\rightarrow-$ Heraeus SC (111), RRR509

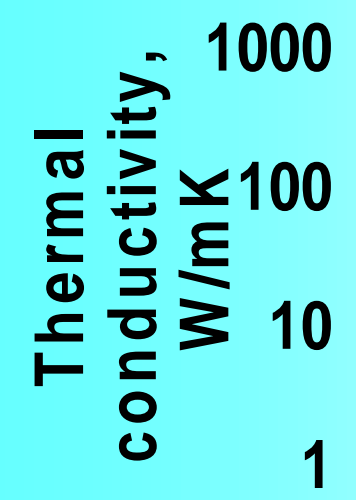

1

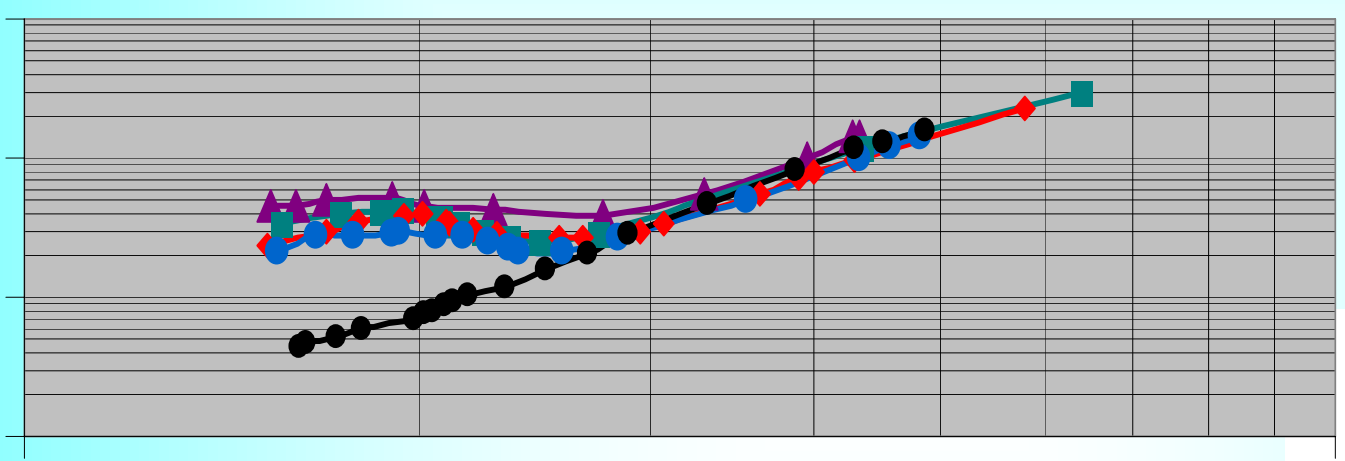

$\mathrm{T}, \mathrm{K}$

Thermal conductivity of single crystals in comparison with polycrystalline material. Phonon peak is clearly pronounced for single crystals.

$$
\lambda(T, R R R G)=R(y) \cdot\left[\frac{\rho_{295 K}}{L \cdot R R R T}+a \cdot T^{2}\right]^{-1}+\left[\frac{1}{D \cdot \exp (y) \cdot T^{2}}+\frac{1}{B \cdot G \cdot T^{3}}\right]^{-1}
$$




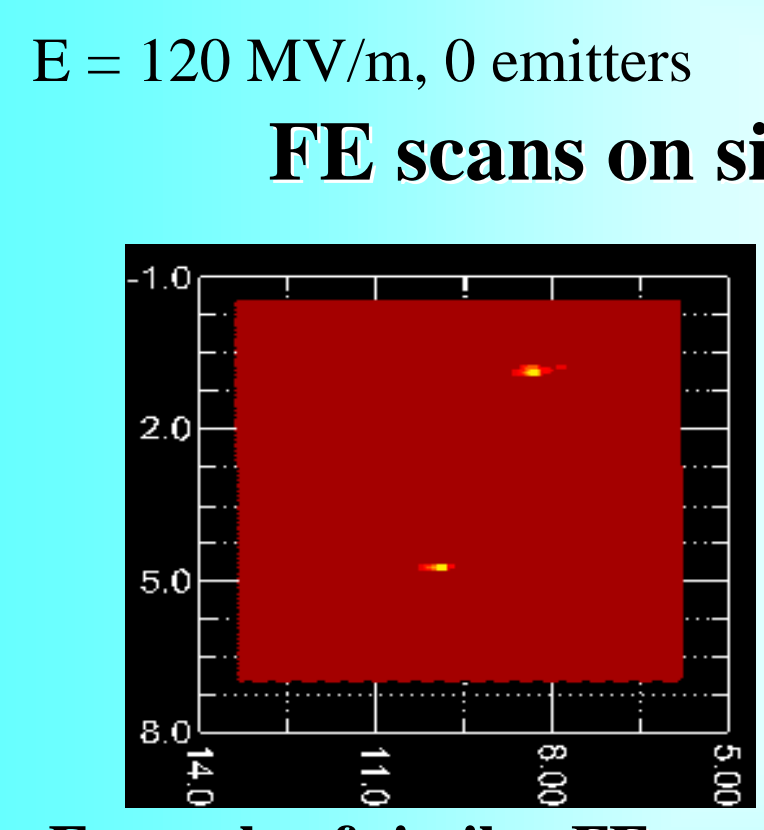

$\mathrm{E}=150 \mathrm{MV} / \mathrm{m}, 2$ emitters

\section{FE scans on single crystal $\mathrm{Nb}$ sample after $30 \mu \mathrm{m}$ BCP.}

Example of similar FE scans on fine grain EP Nb sample. (left) $\mathrm{E}=90 \mathrm{MV} / \mathrm{m}, 3 \mathrm{emitters}$ (right) $\mathrm{E}=120 \mathrm{MV} / \mathrm{m}, 8$ emitters

Field Emission Scanning: A.Dangwal, G.Mueller (Wuppertal)

Surface quality of the BCP treated SC is better as of EP treated polycrystalline $\mathrm{Nb}$ 
 \\ XPS on single crystal with different} crystal orientation (preliminary results)

K.Kowalski, A.Bernasik (SSL, Krakow)

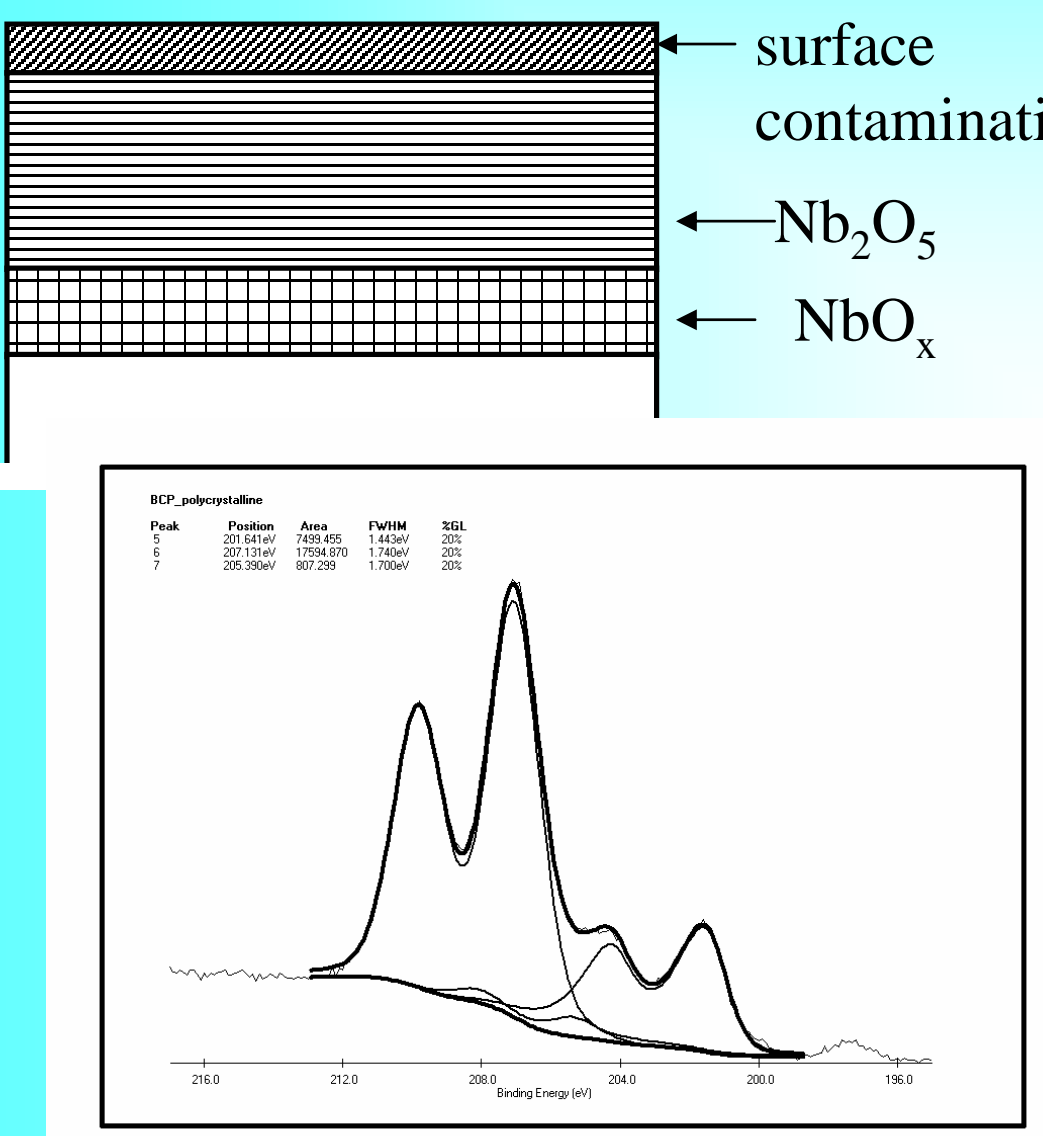

XPS spectrum for BCP polycrystalline $\mathrm{Nb}$

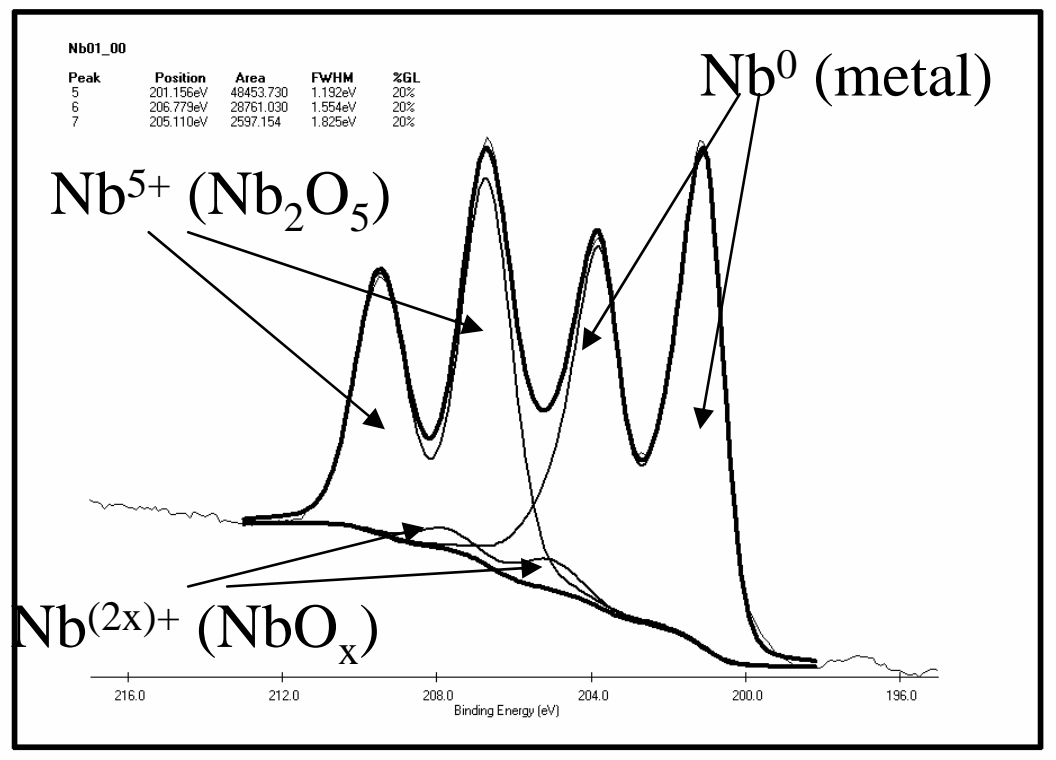

XPS spectrum for BCP single crystal $\mathrm{Nb}$ The oxide layer is thicker in polycrystalline Nb compare to single crystal 


\section{Conclusions}

- Fabrication of single cell and multi cell cavities from large grain niobium by deep drawing and electron beam welding is feasible.

-Accelerating gradient on the level of best fine grain cavities are achievable. A gradient up to $41 \mathrm{MV} / \mathrm{m}$ at $\mathrm{Q}_{0}=1.4 \cdot 10^{10}$ (TB $=2 \mathrm{~K}$ ) was measured after electropolishing. Performance of ca. $30 \mathrm{MV} / \mathrm{m}$ was achieved on the nine cell cavities after only BCP treatment.

- Fabrication of single crystal cavities of ILC size is possible. High Eacc and Q achieved even after rather small BCP and rather short baking 


\section{A lot of aspects of $L G$ and $S C$ have to be understand}

- How to produce SCs of required dimensions ?

- What is the best crystal orientation for the best cavity performance (Hc1, $\mathrm{Hc} 2, \mathrm{Hc} 3$ dependence on crystal orientation)?

- Why the baking works good for BCP treated SCs and LG cavity and is less effective for BCP treated polycrystalline cavities?

- Are the SCs surfaces oxides different compare to polycrystalline $\mathrm{Nb}$ and depend on the crystal orientation of the niobium substrate?

- Is higher onset of field emission for LG and SCs caused only by smooth surface or the mechanism is more sophisticated?

- What is the difference between EP treated and BCP treated grain boundary of LG niobium?

- Why the one dimensional tensile test on LG demonstrates high elongation, but in the two dimensional bulging test the elongation is much smaller?

- What are the exact conditions allowing to connect two SCs in one SC by EB welding and where is the limitation?

- What maximal deformation degree can tolerate the SCs and what is the optimal heat treatment for SCs? 